\title{
Science Club - A Concept
}

\author{
Claas Wegner ${ }^{1}$, Nicole Issak ${ }^{2}, K^{2}$ atharina Tesch2,* and Carolin Zehne ${ }^{1}$ \\ ${ }^{1}$ Department of Biology Didactics, Bielefeld University, Bielefeld, Germany \\ 2, Department of Biology Didactics, Bielefeld University, Bielefeld, Germany \\ For correspondence: carolin_zehne@web.de
}

\begin{abstract}
The following article presents a concept of a science club which was developed by two master's students as a part of their thesis and which has been developed and improved ever since. The extra -curricular concept emphasises pupils' individuality through focusing on problem based leaning, station learning, and mixed age groups. Having joined the club pupils work on topics mainly related to biological phenomena which they explore in experiments. As a collaboration between school and university it is not only intended to foster pupils' interest in science but also to help teacher trainees gain practical experiences in teaching when supervising the club.
\end{abstract}

Keywords: science club, concept, collaboration, extra -curricular offer

\section{Introduction}

After devastating results of international large scale assessments of student performance (such as PISA and TIMSS), the German educational system and its curricula underwent a reform moving towards national educational standards and following the notion of scientific literacy (Neumann et al., 2010).

According to PISA, scientific literacy comprises knowledge of science and science - based technology. This does not only include knowledge of theories of science but also of procedures of scientific enquiry (OECD, 2013). Three competencies are associated with scientific literacy:

- Explain phenomena scientifically

- Evaluate and design scientific enquiry

- Interpret data and evidence scientifically (OECD, 2013, p. 5)

Three types of knowledge are associated with these competencies (1) Content knowledge, which includes knowing about the content of science, (2) procedural knowledge, which means knowing and applying standard procedures of science, as well as (3) an epistemic understanding of science (OECD, 2013).

The goal of the new curricula is to educate scientifically literate persons who have acquired all these competencies related to scientific literacy. This seems especially important when considering the relevance of science in today's society and the impact it has on our daily lives.

Drawing conclusions from the PISA study results, students tend to perform better in countries where schools offer science- related extracurricular activities (OECD, 2012). The strongest relationship in variation of student performance was found in Germany. The analysis showed that not only 
performance was positively affected by science related extracurricular offers but also pupils' attitudes towards science. Attitudes in turn are connected to high levels of involvement (Myers \& Fouts, 1992). Massoni (2011) found that extracurricular activities can result in higher grades and positive attitudes towards school. Pupils build their self-esteem and are trained in "leadership, teamwork, organization, analytical thinking, problem-solving, time management (...), [and discovering] their talents" (Massoni, 2011, p. 86). They also acquire "social, physical, and intellectual skills" (Eccles, 2003, p. 866). As pupils belong to a group over the course of the extracurricular activity, they can establish social networks, and enhance their social competencies when meeting new people and having to work in groups (Massoni, 2011). Also with regards to science-related extracurricular activities, positive effects on performance could be observed (Hong, 2008).

However some pupils show particularly negative attitudes towards science teaching in school while they generally have positive attitudes towards science (Osborne, 2003). This fits the findings of Potvin and Vasni (2014) whose literature review highlighted the importance of school-related variables, such as the type of instruction, for the development of pupils' interest in science.

\section{The Concept of the Club}

Apart from mandatory instruction, many German schools offer diverse extracurricular activities covering many topic areas, such as after school homework supervision as well as various topicspecific clubs for arts, math sports, as well as sciences. Pupils of various age groups can enter the clubs on a voluntary basis. They do not receive any kind of grade during or after their participation in the club.

The concept of a science and experimenting club is one of these extracurricular offers at a German school in the eastern part of North Rhine- Westphalia. Originally developed by two master degree students as a cooperation between a university and a school in 2009, it has been improved and developed ever since.. The club takes places once a week for two hours in the afternoon as a part of the school's extracurricular offer. It is intended for pupils aged 11 to 14 . Any child can enter the club at the beginning of a new school term, yet it is a rather small learning group of 9 to 18 pupils.

Joining the club, pupils deal with various scientific topics, mainly from biology, but also chemistry and physics (see table 1). The concept follows the notion of the constructivist approach to learning, which views learning as an active process which has to be carried out by the pupils themselves. Teachers cannot simply transfer knowledge, but rather have to provide opportunities for leaning to take place (Glasersfeld, 2013). Each pupil has to construct an individual understanding of a particular (scientific) context based on their own experiences and prior knowledge by articulating, discussing and exploring their ideas (Julyan \& Ducworth, 2013). The club incorporates problem-based learning by which pupils get to know basic scientific working methods.

Table 1. Topics of individual lessons of the science and experimenting club.

\begin{tabular}{ll}
\hline Lesson number & \\
\hline 1 & Organizational issues: safety instuctions and introduction: investigating compost \\
2 & Compost and microscope/ binocular in practice I \\
3 & Microscope and binocular in practice II \\
4 & Substances in plants- using dye \\
5 & Extra: competition egg yolk \\
6 & Red cabbage juice as a pH- indicator \\
7 & Saponines- soap in plants \\
8 & Analysis of compost \\
9 & Organizational issues: safety instructions, how does a tea bag rocket work?
\end{tabular}




\begin{tabular}{ll}
10 & Mimosa- sensitive plants \\
11 & Carnivorous plants I \\
12 & Carnivorous plants II and cone hygrometer I \\
13 & Cone hygrometer II and why do apples „rust”? \\
14 & Fall foliage: how are leaves so colorful? \\
15 & Geckos (bionics) \\
16 & Lotus effect (bionics) \\
17 & Shark skin (bionics) \\
18 & Stick insects/ fire salamander \\
19 & Snakes \\
20 & Tarantular \\
21 & Snails \\
22 & Experiments with water \\
23 & Experiments with air \\
24 & Experiments with fire \\
25 & Crystals made out of alum salt \\
26 & Experiments concering water solubility \\
27 & Experimenting with coke \\
28 & Bioluminescence \\
\hline
\end{tabular}

Apart from calling it problem-based learning, there are many other names for the same basic underlying pedagogic principle: inquiry-based learning, experimental learning, constructivist learning etc. Even though there are many names for this way of teaching, they all have in common that they include minimal guidance. This implies that pupils are "placed in inquiry learning contexts asked to discover the fundamental and well known principles of science by modelling the investigatory activities of professional researchers" (Kirschner et al., 2006, p. 76). In this approach, learners encounter problems they do not yet understand, pose questions, explore and observe, and draw conclusions to find answers to their questions (Warner \& Myers, 2008). The club especially stresses learner individuality by putting emphasis on cooperative learning in mixed age groups and learning stations (see figure 1).

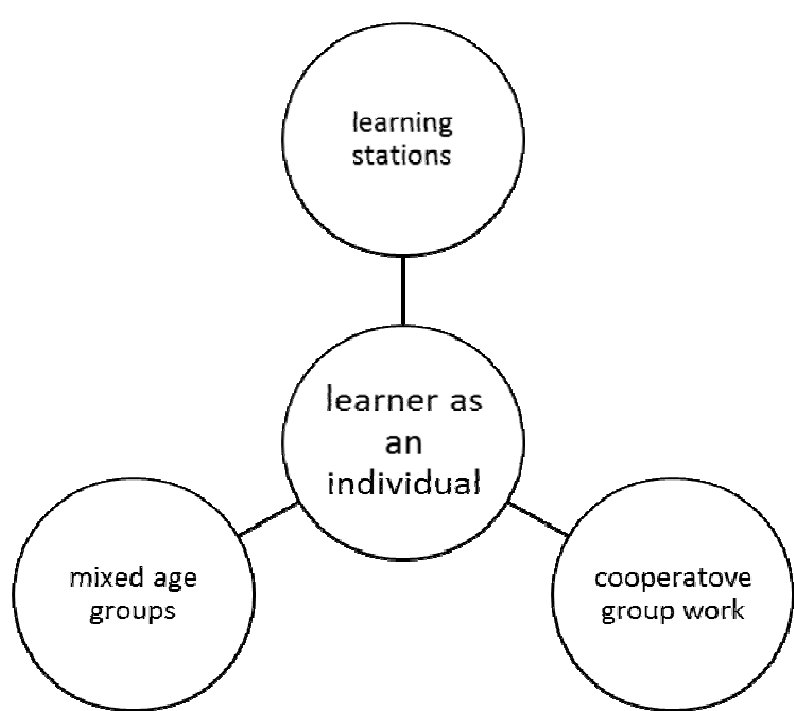

Figure 1. Aspects of acknowledging pupils' individuality as a part of the concept of the club.

Taking part in the science and experimenting club, pupils explore and observe their questions through conducting experiments which were developed by master degree students from Bielefeld University. Figure 2 shows two examples taken from lessons held. Taking into account the 
heterogeneity of the group not only in terms of age but also when it comes to level of performance or aptitude, instructors saw the need for differentiation within the group. This was mainly realized through learning circles, in which pupils work on aspects of the topics mentioned in table 1 in small groups. Most of the time, cooperative learning is used at the individual stations where pupils work in teams to accomplish a common goal in their group, while each of them has an individual task to fulfill. It turns working at the stations into an interactive process with providing feedback and "teaching and encouraging one another" (Felder \& Brent, 2007, p.2).

Experiment: Why does an apple turn brown?

When biting in an apple, it turns brown after a while. But how can we prevent the apple from changing its color? The substance which causes the color is called Melanin. It can also be found in our skin.

Material: apple, lemon juice, plate and knife, airtight container

Cut the apple into four pieces. All of them will receive different treatments:

1. Put the slice on the table (control)

2. drip some lemon juice on the slice

3. put the slice in the fridge

4. put the slice into an airtight container

Note your observations for each treatment. Why does the apple turn brown?

This process is

called

Which factors seem to influence the process? Why does lemon juice stop it / slow it down?
Observing a fire salamander: moving on four legs

Material: fire salamander, gloves

Put the animal on the desk and observe

how it moves. You can also carefully touch

its abdomen to feel how it is moving (use

gloves!)

In what order does the salamander move its legs? How many legs are lifted up in the air at one time? What could be the advantage of having four legs instead of two?

After having watched the movement for a longer period of time, what do you notice? Is the salamander moving in a straight line, sideways or in a curve? Make a sketch of the kind of movement you can observe what does this remind you of?

Use your information sheet and your own observations to create a fact sheet about the salamander you can present to the other groups.
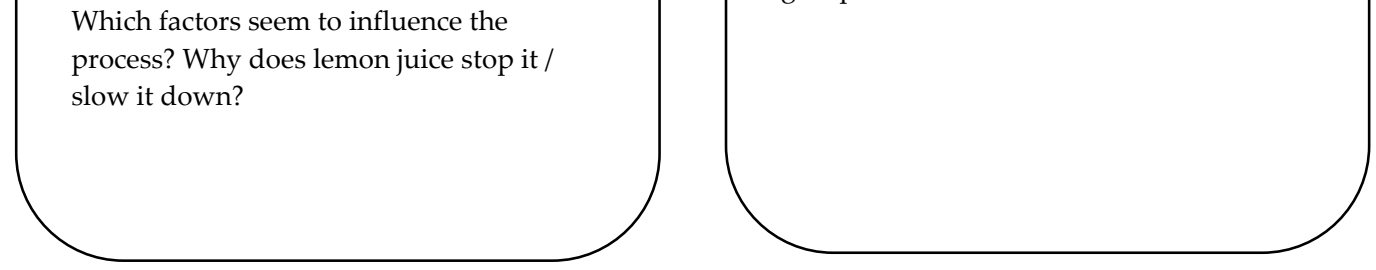

Figure 2. . Examples of work sheets used for experiments in the club

As the club puts emphasis on pupils' individuality, pupils work on problems in mixed age groups. Whole group instruction may not serve all children's learning, as there is a wide span of abilities and skills even in groups of children of the same age. "Prosocial behaviors" (Katz, 1995, p. 3) are more present in mixed age groups. While younger children can observe and learn from older ones' behavior, older children can provide assistance for younger ones in exchange (Gestwicki, 2010). A "collaborative spirit" rather than "competitive tendency" (Rasmussen, 2005, p. 2) seems to prevail in mixed age groups, with less aggression due to a "natural hierarchy" (Gestwicki, 2010, p. 303).

Apart from the instructional efforts to meet children's needs in terms of their individuality, it is also a great opportunity for university students who want to become teachers to gather teaching experience.

The concept of the science and experimenting club tries to recognize and work with pupils' individual differences. Through its working methods such as mixed age groups and station learning it puts a special focus on learner individuality. By moving practical work into the center of the club, pupils get an insight into scientific working methods and might develop further interest in the natural 
sciences. For future teachers, the club is an excellent chance to gather practical experience and to contribute to further improvements of the project.

\section{References}

Bybee, R.W. (1997): Toward an Understanding of Scientific Literacy. In: W. Gräber \& C. Bolte, (Eds): Scientific Literacy- An international symposium. Kiel: IPN, p. 37-68.

Eccles, J.S. (2003). Extracurricular Activities and Adolescent Development. Journal of Social Issues, 59 (4), p.865-889. Retrieved from http://rcgd.isr.umich.edu/garp/articles/eccles03g.pdf

Felder, R.M. \& Brent, R. (2007). Cooperative Learning. In P.A. Mabrouk (Ed.): Active Learning: Models from the Analytical Sciences. Washington: American Chemical Society, p. 34-53.

Gestwicki, C. (2011). Developmentally Appropriate Practice. Curriculum Development in Early Education. Belmont: Wadsworth.

Glasersfeld, E. (2013). Introduction: Aspects of Constructivism. In C. Twomey Fosnot (Ed.): Constructivism: Theory, Perspectives and Practice. New York: Teachers College Press.

Hong, Z.R. (2008). Effects of an Extracurricular Science Intervention on Science Performance, Self-Worth, Social Skills, and Sexist Attitudes of Taiwanese Adolescents from Single- Parent Families. Sex Roles, 59 (7), 555-567.

Julyan, C. \& Duckworth, E. (2013). A Constructivist Perspective on Teaching and Learning Science. In C. Twomey Fosnot (Ed.): Constructivism: Theory, Perspectives and Practice. New York: Teachers College Press.

Katz, L. G. (1995). The Benefits of Mixed Age Grouping. ERIC Clearinghouse on Elementary and Early Childhood Education. Retrieved from http://files.eric.ed.gov/fulltext/ED382411.pdf

Kirschner, P.A., Sweller, J \& Clark, R.E. (2006). Why Minimal Guidance During Instruction Does Not Work: An Analysis of the Failure of Constructivist, Discovery, Problem Based, Experimental, and Inquiry- Based Teaching. Educational Psychologist, 41 (2), 75-86.

Massoni, E. (2011). Positive Effects of Extra Curricular Activities on Students. ESSAI 9(27), 84-87. Retrieved from http://dc.cod.edu/cgi/viewcontent.cgi?article=1370\&context=essai

Myers, R. E. \& Fouts, J. T. (1992). A cluster analysis of high school science classroom environments and attitude toward science. Journal of Research in Science Teaching, 29, 929-937

Neumann, K., Fischer, H.E.\& Kauertz, A. (2010). From PISA to Educational Standards: The Impact of Large- Scale Assessments on Education in Germany. International Journal of Science and Mathematics Education 8, 545-563.

OECD (2012). Are Students More Engaged When Schools offer Extracurricular Activities? PISA in Focus, 7. Retrieved from: http://www.oecd.org/edu/pisa\%20in\%20focus\%20n18\%20(eng)--v05.pdf

OECD (2013). PISA 2015- Draft Science Framework. Retrieved from http://www.oecd.org/pisa/pisaproducts/Draft\%20PISA\%202015\%20Science\%20Framework\%20.pdf

Osborne, J., Simon, S., \& Collins, S. (2003). Attitudes towards science: A review of the literature and its implications. International Journal of Science Education, 25(9), 1049-1079.

Potvin, P., \& Hasni, A. (2014). Interest, motivation and attitude towards science and technology at K-12 levels: a systematic review of 12 years of educational research. Studies in Science Education, 50(1), 85-129.

Rasmussen, M.F. (2005). Mixed Age Groups in After-School and Out-Of- School Time Programs. Extension Extra. Retrieved from http://pubstorage.sdstate.edu/AgBio_Publications/articles/ExEx15013.pdf

Warner, A.J \& Myers, B.E. (2008). What Is Inquiry- Based Instruction? Department of Agricultural Education and Communication, Institute of Food and Agricultural Sciences. Retrieved from: https://edis.ifas.ufl.edu/pdffiles/WC/WC07500.pdf 